\title{
ACTIVITY-BASED COSTING OF CANNED AND PROCESSED FOODS BUSINESSES IN THAILAND: EFFECTS ON ORGANIZATIONAL DEVELOPMENT, BUSINESS COMPETITIVENESS AND CORPORATE SUCCESS
}

\author{
Phaprukbaramee USSAHAWANITCHAKIT
}

\author{
Mahasarakham Business School, Mahasarakham University, Thailand \\ E-mail: markarlington@hotmail.com
}

Received 17 May 2017; accepted 25 September 2017

\begin{abstract}
This study aims at investigating the relationships among activity-based costing, organizational development, business competitiveness, and corporate success of canned and processed foods businesses in Thailand. In this study, 142 canned and processed foods businesses in Thailand are the samples of the study. Structural equation model (SEM) was employed to test the research relationships. The research results indicate that activity-based costing positively leads to organizational development and business competitiveness. Also, organizational development positively relates to business competitiveness and corporate success while business competitiveness positively affects corporate success. In summary, activity-based costing plays a significant role in determining, driving and explaining firm outcomes. Accordingly, firms need to pay attention to the development and utilization of activity-based costing through the provision of competencies, capabilities, resources, and assets to its implementation. To verify the current study, future research may need to search for activity-based costing's dimensions and components, collect data from different populations and countries and apply regression analysis, partial least squared and path analysis to prove the relationships.
\end{abstract}

Keywords: activity-based costing, organizational development, business competitiveness, corporate success, canned and processed foods businesses.

JEL classification: M41.

\section{Introduction}

Recently, firms have dealt with rapidly changing competitive markets and environments. They need to determine and utilize valuable organizational strategies, provide and benefit effective operational techniques and build and implement best business practices in order to gain success, stability, survival, and sustainability within these markets and environments. Several strategies, techniques and practices from marketing, management, accounting, and other disciplines are applied to help firms achieve their objectives, purposes and goals. In this study, activity-based costing as a strategic tool from management accounting is a key determinant of firms' performance, profitability and survival. It is one of the most innovative and sophisticated management accounting techniques (Diavastis et al. 2016).
It critically leads to financial performances, namely cost reduction, full control and ongoing performance and financial benefits and non-financial performances including enhanced employee productivity and operational efficiency. Firms with effective activity-based costing implementation tend to manage their resources, assets, competencies, and capabilities successfully, provide accurate cost information efficiently and reduce non-valuable costs and expenses excellently (Maiga 2014). They have attempted to use activity-based costing in doing businesses and operations for obtaining their outcomes. Thus, activity-based costing is important and it is proposed to drive, explain and create firms' success in the current and future aspects and in the long-term perspectives. Here, activity-based costing tends to influence organizational development, business

\footnotetext{
Copyright (c) 2017 The Authors. Published by VGTU Press.

This is an Open Access article distributed under the terms of the Creative Commons Attribution License (http://creativecommons.org/licenses/by/4.0/), which permits unrestricted use, distribution, and reproduction in any medium, provided the original author and source are credited..
} 
competitiveness and corporate success in rigorous situations, circumstances and climates.

Activity-based costing is one of strategic management accounting techniques and it is an important management accounting innovation for well over a decade (Innes et al. 2000). It refers to a costing method that first assigns overhead costs to activities and to products, orders, or customers based upon their consumption of the different activities (Huang et al. 2014). It allocates resource costs to products based on activities, which are the factors causing work and incurring cost, used by products or services. Also, activitybased costing is defined as an assignment of overhead costs to products and processes by computations intended to approximate cause-and-effect relationships in the production process (Mishra and Vaysman 2001). It provides better information to decision makers. Then, activity-based costing can enhance firms to maintain success, stability, survival, and sustainability in rigorously competitive markets and environments. In existing literature, activity-based costing comprises of three stages, namely (1) the mapping of activities and processes, (2) the allocation of resources to activities and (3) the consumption of activities by objects of cost (Elhamma 2012). In using activity-based costing system, firms need to identify their activities, determine the resources consumed by a product or a services are allocated to the various activities used by this product or service and allocate activity costs to objects of cost through the cost driver. Firm with successful activity-based costing implementation tend to provide accurate cost information to management and obtain lower costs, improved quality and reduced manufacturing cycle time. Accordingly, they can utilize activity-based costing system to gain cost accuracy, cost reduction and cost excellence that lead to sustainable competitive advantage, superior performance and longterm growth. Thus, activity-based costing is a significant innovation in management accounting and it is a main determinant of firm' performance and outcome. Hence, this study attempts to verify and investigate the influences of activity-based costing on organizational development, business competitiveness and corporate success.

Interestingly, this study collects data from canned and processed foods businesses in Thailand. Canned and processed foods businesses are one of major industries in Thailand's economy. They have continuously invested in new product development, technology and research and development. They have a commitment to international quality standards that helps Thailand's foods industry continue to develop and grow. However, competition in canned and processed foods businesses in Thailand is rigorously intense. These businesses need to apply a valuable approach, such as activity-based costing in order to improve their operations and practices and achieve superior performance and success in the long-term. Accordingly, they are likely to use activity-based costing in providing cost management through cost allocation for obtaining cost accuracy, cost reduction and cost excellence. Thus, canned and processed foods businesses in Thailand are the appropriate samples of the study.

In this study, the relationships between activity-based costing and corporate success are empirically investigated. This study attempts to examine the effects of activity-based costing on organizational development, business competitiveness and corporate success of canned and processed foods businesses in Thailand. The key research question in this study is how activity-based costing leads to corporate success. The specific research questions are: (1) How activity-based costing relates to organizational development and business competitiveness, (2) How organizational development influences business competitiveness and corporate success, and (3) How business competitiveness impacts corporate success.

The rest of this study is organized as follows. Firstly, relevant literature review of activity-based costing and its consequences is addressed and hypotheses development is presented. Secondly, the research methods are discussed including the sample of the study, sample selection, data collection procedure, measurements of variables, and statistical techniques. Thirdly, the results of the study are presented and the reasonable discussions are shown. Finally, contributions for theory and management, limitations of the study and suggestions and directions for future research are pointed out.

\section{Literature review and hypotheses development}

Here, knowledge-based view theory systematically explains the effects of activity-based costing on corporate success. It points out an organization as a generator and an integrator of knowledge to establish and exploit a sustainable competitive advantage (Grant 1996). Knowledge is a source of firms' competitive advantage and it helps create sustainable competitive advantage and superior performance. In this study, activity-based costing is also a firm's knowledge and it reflects their competencies and capabilities of managing costs well. More successful activity-based costing implementation is likely to affect best business outcomes, namely organizational development, business competitiveness and corporate success. Thus, the hypothesized relationships are discussed later.

\subsection{Activity-based costing}

In succeeding in the highly and rigorously competitive markets and environments, a valuable business approach is implemented to help firms obtain competitive advantage and achieve outstanding performance. Activity-based costing is one of innovative management accounting techniques and 
it is an important cost management approach that encourages firms to gain efficiency, effectiveness, success, growth, survival, and sustainability. In this study, activity-based costing is defined as an accounting method that focuses on allocation of overhead costs to products or services (Stevenson and Cabell 2002). In implementing activitybased costing, costs are accumulated in an activity pool and then allocated to specific products or services by using cost drivers. These cost drivers can be direct labor hours, machine hours, direct labor cost, a number of set up or others. A cost driver is an event associated with an activity that results in the consumption of the firms' resources (Gupta and Galloway 2003). It is a factor that causes or drives an activity's costs. Firms with effective activity-based costing implementation tend to provide a more accurate way of calculating product costs through identifying systematic cause and effect linkages among products, markets and costs. Thus, they have promoted and adopted activity-based costing for assessing continuous improvement, for monitoring process performance, for making strategic decisions, and for improving profit performance (Cagwin and Bouwman 2002). Accordingly, activity-based costing is a well known technique for accurately costing products and potentially providing cost data and management information to facilitate decision making well. In addition, activity-based costing refers to an accounting approach that is designed with the objective of providing accurate cost information by using cost drivers to assign activity costs to products, services or customers related these activities (Banker et al. 2008). It presents a more structured approach to evaluate the expenses associated with specific activities used to support a product, a service or a customer. In applying activity-based costing, firms can allocate costs to activity pools of operating activities that consume costs and allocate from each activity pool to individual cost objects based on their usage of activities (Lu et al. 2016). Then, activity-based costing can help firms obtain cost accuracy and provide valuable cost information to support potential decision making.

Activity-based costing is important and it can help firms succeed, survive and sustain in complex competitive situations. It provides more accurate cost information and improves product cost and cost reduction and helps decision making through better cost controls and asset utilization and coupled with greater use of financial leverage to enhance performance measurements (Kursat Onat et al. 2014). It also provides better cost data and management information to successfully make a decision well in business operations and practices and effectively maintain firm profitability (Innes et al. 2000). Thus, firms with successful activity-based costing implementation tend to have superior performance in long-term aspect and gain growth, survival and sustainability in highly dynamic competitive environments. Similarly, successful activity-based costing implementation explicitly leads to enlarged employee productivity, enhanced product and service quality, increased operational efficiency, cost reduction, full control of ongoing performance, and improved financial benefits (Diavastis et al. 2016). According to efficient activity-based costing implementation, firms can create and build competitive advantage, gain and obtain performance and profitability and achieve and maintain success, stability, growth, survival, and sustainability. Likewise, firms can use activity-based costing to produce accurate cost information for potential decision making relating to building customer satisfaction and creating market acceptance that lead to superior longrun financial performance and increase long-term firm profitability (Goebel et al. 1998). Thus, they are likely to improve and maintain the best business outcomes in the current and future perspectives. In this study, these best business outcomes comprise of organizational development, business competitiveness and corporate success. Firstly, activity-based costing promotes firms' organizational development by identifying non-value adding activities and focusing on more realistic view via detecting and eliminating waste. Secondly, activity-based costing adds to firm competitiveness and value through providing cost accuracy, cost efficiency, cost effectiveness, cost reduction, and cost advantage. It is likely to enhance business competitiveness. Lastly, activity-based costing encourages firms to achieve their goals, namely profitability, performance, stability, growth, survival, and sustainability. Accordingly, it seems to have a positive effect on corporate success. Hence, activity-based costing is a key determinant of these business outcomes and the relationships between activity-based costing and its consequences are positive. Therefore,

$\mathrm{H} 1$ : Activity-based costing positively leads to (a) organizational development, (b) business competitiveness and (c) corporate success.

\subsection{Organizational development}

As discussed earlier, activity-based costing plays a significant role in determining, explaining and driving firms' organizational development. Organizational development is the first outcome of activity-based costing implementation and it is defined as a process which firms have adopted a series of planned intervention strategies that aim to enhance organizational effectiveness and well-being of organizational members (Mulili, Wong 2011). It uses psychology, communication, sociology, human relations and organizational behavior as valuable methods and approaches to help firms develop their abilities, competencies and capabilities in rigorously competitive environments. It requires an organization to invest in developing people capability and focusing on long-term sustainable organizational effectiveness in changing environments (Foster 2013). Under 
organizational development-based aspects, firms attempt to create a challenging work within innovative environments, to provide opportunities for organizational members to develop their potentiality and productivity and to support to increase firms' organizational effectiveness relating to their goals and objectives. In existing literature, organizational development comprises of five characteristics, including (1) a planned proactive process as opposed to being a reactive activity, (2) an entire organization or a large part on an organization, (3) being initiated and management from a top level of an organization, (4) an enhancement of an organization's problem solving and renewal processes so that the organization is able to achieve its goals and objectives and promote well-being of organizational members, and (5) planned change or interventions made with the help of change agents or third parties who are familiar with the behavioral sciences and action research (French and Bell 1990). Firms with successful organizational development can continuously improve their operations, activities and practices, increase their long-term performance and profitability and maintain their growth, survival and sustainability. Also, organizational development refers to a system-wide application and transfer of behavioral science knowledge to the planned development, improvement and reinforcement of the strategies, structures and processes that lead to organizational effectiveness and well-being of organizational members (Ravichandran and Bano 2016). It positively improves work environment, individual knowledge, skill attitude and behavior. Organizational development-oriented firms can encourage employee satisfaction, create and sustain competitive advantage and obtain and increase performance and success. Accordingly, organizational development is likely to create business competitiveness and improve corporate success. Thus, it tends to become a key determinant of business competitiveness and corporate success. Therefore,

$\mathrm{H} 2$ : Organizational development positively leads to (a) business competitiveness and (b) corporate success.

\subsection{Business competitiveness}

Activity-based costing is a key factor that affects firms' competitive position and it positively enhances firms to increase business competitiveness. It leads to their competitiveness that relates to superior success and long-term survival. Then, business competitiveness is a significant outcome of successful activity-based costing implementation and it refers to an ability of firms to make a business difficult to be replaced by competitors (Chuang and Huang 2015). It can help firms maintain their profit margins and revenue growth. The business difficult comprises of maximizing revenue thru differentiation, minimizing cost thru efficiencies, and focusing on a niche market (Uy 2014). To remain competitive, firms need to be able to adapt to new demands from existing and new markets. Firms with increased business competitiveness can obtain their superior success in highly turbulent environments. They are likely to gain success in doing business. In addition, business competitiveness is defined as an ability of firms to sustain their long-term performance better than their competitors in the markets (Venter et al. 2014). Under competitiveness of firms, attracting potential customers, saving the time for establishing business relationship with customers, reducing transaction costs, and creating premium revenue are characteristics of maintaining competitive position. They can achieve more profitability, market share, sales, and growth rate. To obtain competitiveness, firms need to adapt to competitors' environments with fast answers, improving and reforming operational processes and implementing valuable strategies appropriately. Then, business competitiveness is an important mechanism for improving firms' performance, success and growth. Likewise, business competitiveness is defined as the sustained capacity to gain and maintain a profitable market share (Solleiro and Castanon 2005). It encourages firms to obtain and improve firms' performance, success and survival. Firms with sustainable business competitiveness can strengthen their performance and profitability through increasing productivity and participating in different environments successfully. Hence, business competitiveness is likely to become a significant determinant of corporate success. Also, business competitiveness is ultimately concerned with firms' long-term performance that relates to their competitors (Man et al. 2002). It comprises of long-term orientation of performance, controllability of various resources and capabilities links to external conditions, relativity of competencies to industrial measures, and dynamic transformation of competitive potentials through the competitive process into outcomes. It is an ability of firms to match and improve their capabilities, competencies, offerings, and potentialities via that act and react through creating their cost superiority and financial strength. Thus, business competitiveness tends to positively influence corporate success and it is hypothesized to have a positive effect on corporate success. Therefore,

H3: Business competitiveness positively leads to corporate success.

\subsection{Corporate success}

An outcome of activity-based costing, organizational development and business competitiveness is a firm's corporate success. They are factors which influence their success. In this study, corporate success refers to an outcome of doing and operating business efficiently and effectively. It reflects to a high level of confidence in firms' abilities, competencies and capabilities to achieve their goals and objectives (Ahmad et al. 2010). Its measurements comprises of financial characteristics, such as sales turnover, sales 
growth, annual sales, market share, return on assets, sales margins, a number of employees, and survival rates, and non-financial characteristics, such as customer satisfaction, customer retention, personal development, a sense of personal achievement, owner's self-satisfaction, firm's image and reputation, employee's satisfaction, good workplace relations, and owner lifestyle and social responsibility (Rahman et al. 2015). These financial characteristics seem to focus on short-term perspectives while non-financial perspectives tend to emphasize long-term perspectives. Accordingly, greater corporate success is likely to create increased long-term survival. In addition, corporate success can be measured into subjective and objective indicators (Danes and Olson 2003). The subjective indicators provide a view into issues of organizational commitment and the desire to work through tough times while the objective indicators measure performance. This study uses five indicators of sales growth, sales margins, market share, return on assets, and executive satisfaction to measure firms' corporate success. Thus, corporate success is an important consequence of successful activity-based costing implementation.

In summary, the research relationships among activitybased costing, organizational development, business competitiveness, and corporate success are shown in Figure 1.

\section{Research methods}

\subsection{Sample selection and data collection procedure}

From Thai foods processors' association, there are only 150 canned and processed foods businesses in Thailand. Thus, all canned and processed foods businesses are the samples of the study. They are the appropriate samples of the study because competition in canned and processed foods businesses in Thailand is rigorously intense. Then, activitybased costing can help provide successful cost management through cost allocation for obtaining cost accuracy, cost reduction and cost excellence. In existing literature, activity-based costing becomes very complex, costly and time consuming according to various cost pools and suitable cost drivers for them tanks (Bazrafshan and Karamshahi 2017). It has been along hardship and problems such as resistance of personnel, uncertainties, implementation and execution problems and the need for accurate and timely data. However, activity-based costing has a beneficial outcome and a valuable advantage for canned and processed foods businesses in Thailand. Greater activity-based costing implementation tends to relate to more corporate success in the rigorous competitive markets and environments. A mail survey procedure via questionnaire was used for data collection. With regard to the questionnaire mailing, 145 responses were received. Of the surveys completed and returned, 142 were usable. The effective response rate was approximately $94.67 \%$. According to Aaker et al. (2001), the response rate for a mail survey, with an appropriate follow-up procedure, if greater than $20 \%$ is considered acceptable. In addition, to examine potential non-response bias and to detect possible problems with non-response errors, the assessment and investigation of non-responsebias were centered on a comparison of the first and the second wave data as recommended by Armstrong and Overton (1977). In this regard, neither procedure showed significant differences because there were no statistically significant differences between first and second groups at a 95\% confidence level as firm age $(t=0.09, p>.05)$, firm size $(\mathrm{t}=0.13, \mathrm{p}>.05)$ and firm capital $(\mathrm{t}=0.11, \mathrm{p}>.05)$.

\subsection{Measures}

All constructs were measured using a 5-point Likert scale ( $1=$ strongly disagree to $5=$ strongly agree), except from firm size, firm age, and firm capital. Appendix 1 presents the measurements of all variables in this study. Firstly, corporate success is an outcome of doing and operating business efficiently and effectively. Five-item scale was developed to gauge how firms achieve sales growth, sales margins, market share, return on assets, and executive satisfaction. Secondly, activity-based costing is an accounting method that focuses on allocation of overhead costs to products or services (Stevenson and Cabell 2002). Seven-item scale was created to assess how firms allocate costs to activity pools of operating activities that consume costs and allocate from each activity pool to individual cost objects based on their usage of activities. Thirdly, organizational development is a process which firms have adopted a series of planned intervention strategies that aim to enhance organizational

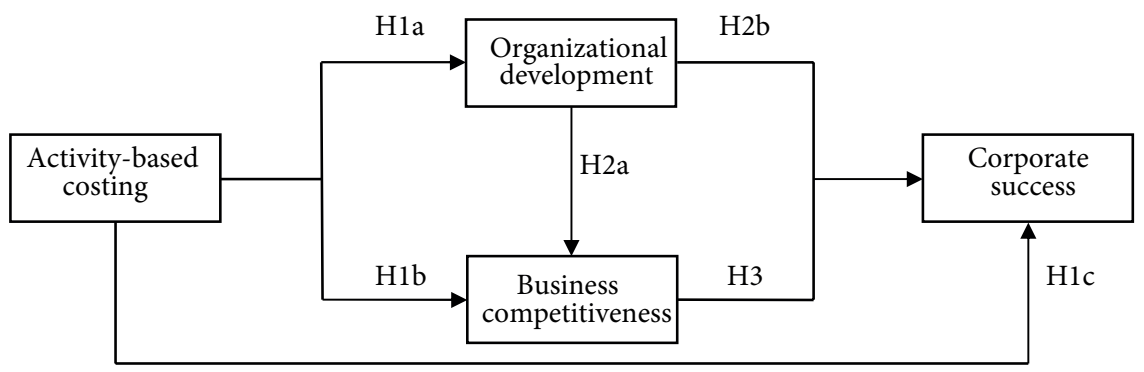

Fig. 1. Conceptual model of the relationships between activity-based costing and corporate success 
effectiveness and well-being of organizational members (Mulili and Wong 2011). Four-item scale was initiated to evaluate how firms create a challenging work within innovative environments, provide opportunities for organizational members to develop their potentiality and productivity and increase their organizational effectiveness relating to their goals and objectives. Lastly, business competitiveness is an ability of firms to make a business difficult to be replaced by competitors (Chuang and Huang 2015). Fouritem scale was introduced to measure how firms provide long-term orientation of performance, controllability of various resources and capabilities links to external conditions, relativity of competencies to industrial measures, and dynamic transformation of competitive potentials through the competitive process into outcomes. For the control variables, firm age (FA) may influence a firm's technological learning capacity, implementing business activities, actions and strategies, and the profitability of organizational operations (Zahra et al. 2000). It was measured by the number of years a firm has been in existence. Next, firm size (FS) may affect the ability to learn and diversify operations, and to compete and survive in the markets (Arora and Fosfuri 2000). It was measured by the number of employees in a firm. In addition, firm capital (FC) may impact the capacity of a firm to implement business methods and strategies in order to achieve competitive advantage and superior performance (Ussahawanitchakit 2007). It was measured by the amount of money a firm has invested in doing business.

\subsection{Methods}

To verify the validity and reliability of the research tool, factor analysis was conducted separately on each set of the items representing a particular scale due to limited observations. This analysis has a high potential to inflate the component loadings. All factor loadings with values of 0.76-0.92 are greater than the 0.40 cut-off and are statistically significant (Nunnally and Bernstein 1994). Also, discriminant power was utilized to gauge the validity of the measurements by item-total correlation. In the scale validity, item-total correlation with values of $0.77-0.91$ is greater than 0.30 (Churchill 1979). Likewise, the reliability of the

Table 1. Results of measure validation

\begin{tabular}{|l|c|c|c|}
\hline \multicolumn{1}{|c|}{ Items } & $\begin{array}{c}\text { Factor } \\
\text { loadings }\end{array}$ & $\begin{array}{c}\text { Item-total } \\
\text { correlation }\end{array}$ & $\begin{array}{c}\text { Cronbach } \\
\text { alpha }\end{array}$ \\
\hline Corporate success (CS) & $0.81-0.89$ & $0.82-0.88$ & 0.88 \\
\hline $\begin{array}{l}\text { Activity-based costing } \\
\text { (AC) }\end{array}$ & $0.76-0.85$ & $0.77-0.85$ & 0.91 \\
\hline $\begin{array}{l}\text { Organizational } \\
\text { development (OD) }\end{array}$ & $0.85-0.92$ & $0.85-0.91$ & 0.91 \\
\hline $\begin{array}{l}\text { Business competitiveness } \\
\text { (BC) }\end{array}$ & $0.83-0.88$ & $0.85-0.87$ & 0.87 \\
\hline
\end{tabular}

measurements was evaluated by Cronbach alpha coefficients. In the scale reliability, Cronbach alpha coefficients with values of $0.87-0.91$ are greater than 0.70 (Nunnally and Bernstein 1994). The scales of all measures appear to produce internally consistent results and they are deemed appropriate for further analysis. Accordingly, they express an accepted validity and reliability in this study, resulting in Table 1.

The structural equation model (SEM) is conducted to investigate the relationships among activity-based costing, organizational development, business competitiveness, and corporate success. Because all variables in this study were neither nominal data nor categorical data, the structural equation model is an appropriate method for examining the hypothesized relationships.

\section{Results and discussion}

Table 2 presents the descriptive statistics and correlation matrix for all variables. Multicollinearity might occur when inter-correlation in each predict variable is more than 0.80 , which is a high relationship (Hair et al. 2010). The correlations ranging from 0.55 to 0.78 at the $p<0.01$ level, which means that the possible relationships of the variables in the conceptual model could be tested. Thus, there are no substantial multicollinearity problems encountered in this study.

Table 3 presents the results of path coefficients and hypotheses testing of the research relationships. Figure 2 shows a summary of the activity-based costing-corporate success relationships. In this study, the goodness of fit of the models, including the goodness of fit index (GFI) with value of 0.94 , the comparative fit index (CFI) with value of 0.97 , the incremental fit index (IFI) with value of 0.92 , and the root mean square error of approximation (RMSEA) with value of 0.04 are considered (Herda and Lavelle 2012). This study shows that the initial test of the measurement model

Table 2. Descriptive statistics and correlation matrix

\begin{tabular}{|l|c|c|c|c|}
\hline \multicolumn{1}{|c|}{ Variables } & CS & AC & OD & BC \\
\hline Mean & 3.80 & 4.19 & 3.96 & 3.95 \\
\hline $\begin{array}{l}\text { Standard } \\
\text { Deviation }\end{array}$ & 0.71 & 0.57 & 0.72 & 0.65 \\
\hline $\begin{array}{l}\text { Corporate success } \\
\text { (CS) }\end{array}$ & $0.55^{\star * *}$ & & & \\
\hline $\begin{array}{l}\text { Activity-based } \\
\text { costing (AC) }\end{array}$ & $0.76^{* * *}$ & $0.55^{\star * *}$ & & \\
\hline $\begin{array}{l}\text { Organizational } \\
\text { development } \\
\text { (OD) }\end{array}$ & $0.74^{* * *}$ & $0.57^{* * *}$ & $0.78^{* * *}$ & \\
\hline $\begin{array}{l}\text { Business competi- } \\
\text { tiveness (BC) }\end{array}$ & & & & \\
$* * *$ p $<.01$ & & & & \\
\hline
\end{tabular}


Table 3. Results of path coefficients and hypotheses testing

\begin{tabular}{|l|c|c|c|l|}
\hline $\begin{array}{c}\text { Hypo- } \\
\text { theses }\end{array}$ & $\begin{array}{c}\text { Relation- } \\
\text { ships }\end{array}$ & Coefficients & t-value & \multicolumn{1}{|c|}{ Results } \\
\hline H1a & AC $\rightarrow$ OD & $0.77^{* * *}$ & 5.21 & Supported \\
\hline H1b & AC $\rightarrow$ BC & $0.21^{\star}$ & 1.79 & Supported \\
\hline H1c & AC $\rightarrow$ CS & 0.03 & 0.37 & Not supported \\
\hline H2a & OD $\rightarrow$ BC & $0.75^{* * *}$ & 6.81 & Supported \\
\hline H2b & OD $\rightarrow$ CS & $0.60^{* * *}$ & 4.75 & Supported \\
\hline H3 & BC $\rightarrow$ CS & $0.21^{\star}$ & 1.66 & Supported \\
\hline
\end{tabular}

${ }^{*} \mathrm{p}<.10,{ }^{* * *} \mathrm{p}<.01$

resulted in a good fit to the data. Firstly, GFI value is an index that ranges from 0 to 1 , with value over 0.90 indicating a relatively good fit (Byrne 1998). Secondly, CFI values always lie between 0 and 1 , with values over 0.90 indicating a relatively good fit (Bentler 1990). Thirdly, IFI values exceeding 0.90 indicate a relatively good fit (Kline 1998). Lastly, a RMSEA value of less than 0.05 indicates a close fit and less than 0.08 suggests a marginal fit (Bollen and Long 1993).

In this study, the relationships among activity-based costing, organizational development, business competitiveness, and corporate success are investigated. Activity-based costing plays an important role in determining, driving and explaining organizational development and business competitiveness. It positively leads to organizational development $(b=0.77, p<0.01)$ and business competitiveness $(b=$ $0.21, \mathrm{p}<0.08)$. It is designed with the objective of providing accurate cost information by using cost drivers to assign activity costs to products, services or customers related these activities (Banker et al. 2008). It provides better cost data and management information to successfully make a decision well in business operations and practices through enlarged employee productivity, enhanced product and service quality, increased operational efficiency, cost reduction, and full control of ongoing performance and effectively improve financial benefits and maintain firm profitability (Innes et al. 2000). Accordingly, firms with effective activity-based costing implementation can provide organizational development and increase business competitiveness. They can develop and improve organizational operations, activities and practices, create and build competitive advantage, gain and obtain performance and profitability and achieve and maintain success, survival and sustainability. Thus, activitybased costing is positively related to organizational development and business competitiveness. Therefore, Hypotheses $1 \mathrm{a}-1 \mathrm{~b}$ are supported. In contrast, activity-based costing has no influence on corporate success and it does not lead to corporate success $(b=0.03, p<0.72)$. In general, activitybased costing system is implemented for assessing continuous improvement, for monitoring process performance, for making strategic decisions, and for improving profit performance (Cagwin and Bouwman 2002). It seems to have a direct effect on obtaining cost accuracy and providing valuable cost information to support potential decision making in doing business. Greater decision making can determine more success of firms' operations, activities and practice in highly competitive environments. Then, activitybased costing is likely to have an indirect impact on corporate success. Hence, it does not relate to corporate success. Therefore, Hypothesis 1c is not supported.

Interestingly, organizational development is a key determinant of business competitiveness and corporate success and it has an important influence on business competitiveness and corporate success. It positively leads to business competitiveness $(b=0.75, p<0.01)$ and corporate success $(\mathrm{b}=0.60, \mathrm{p}<0.01)$. According to a study of Mulili and Wong (2011), organizational development is a process which firms have adopted a series of planned intervention strategies that aim to enhance organizational effectiveness and well-being of organizational members through valuable methods and approaches of their abilities, competencies and capabilities in rigorously competitive environments. Firms with successful organizational development can create a challenging work within innovative environments, provide opportunities for organizational members to develop their potentiality and productivity and support to increase firms' organizational effectiveness relating to their goals and objectives. Achieving goals of organizational development can help firms gain and increase their competitive advantage and achieve and improve their success. Thus, organizational development positively relates to business competitiveness

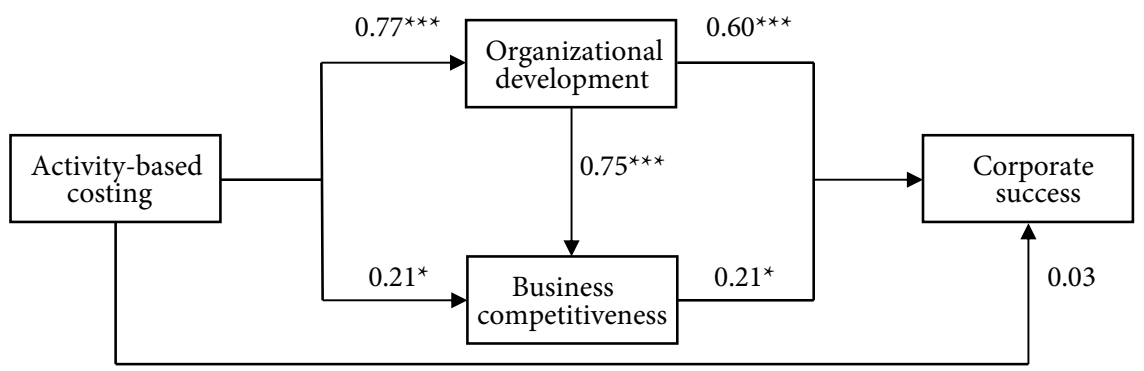

${ }^{*} \mathrm{p}<.10,{ }^{* *} \mathrm{p}<.01 ; \mathrm{GFI}=0.94 ; \mathrm{CFI}=0.97 ; \mathrm{IFI}=0.92 ; \mathrm{RMSEA}=0.04$

Fig. 2. A summary of the activity-based costing-corporate success relationships 
and corporate success. More effective organizational development affects greater corporate success. Therefore, Hypotheses $2 \mathrm{a}-2 \mathrm{~b}$ are supported.

Similarly, business competitiveness is a significant factor that affects corporate success and it critically links to corporate success. It is a positive effect on corporate success $(b=$ $0.21, \mathrm{p}<0.10)$. In existing literature, business competitiveness is a significant outcome of successful activity-based costing implementation and it refers to an ability of firms to make a business difficult to be replaced by competitors (Chuang and Huang 2015). It comprises of maximizing revenue thru differentiation, minimizing cost thru efficiencies, and focusing on a niche market (Uy 2014). Firms with sustained business competitiveness can attract potential customers, save time for establishing business relationship with customers, reduce transaction costs, and create premium revenue which are characteristics of maintaining competitive position. They need to be able to adapt to new demands from existing and new markets and competitors' environments with fast answers, improving and reforming operational processes and implementing valuable strategies appropriately. Accordingly, business competitiveness is an important mechanism for improving firms' performance, success and growth. It positively leads to corporate success in the turbulent markets and environments. Therefore, Hypothesis 3 is supported.

In summary, activity-based costing is a source of organizational development and business competitiveness while organizational development significantly affects both business competitiveness and corporate success. Also, business competitiveness plays an important role in determining corporate success. However, activity-based costing does not lead to corporate success. Hence, firms need to create, implement and improve activity-based costing well in order to obtain and increase firms' outcomes through competitive advantage, performance, success, survival, and sustainability. Greater effective activity-based costing implementation can affect more increased organizational results.

\section{Contributions and directions for future research}

\subsection{Theoretical contribution and directions for future research}

This study attempts to link activity-based costing to corporate success via organizational development and business competitiveness as the connectivity of the relationships. In this study, activity-based costing has an indirect influence on corporate success. As a result, this study confirms the existing literature of activity-based costing and its consequences. To expand and increase the current study, future research may need to search for activity-based costing's dimensions and components, propose them as the independent variables of the study and investigate the hypothesized relationships. Also, future research is needed to test the generalizability of the study by collecting data from different populations and countries. Likewise, this study focuses on only firm age, firm size and firm capital as the control variables. Future research may put other control variables, such as firm heterogeneity, exporting experience and time effects, in the study in order to add research benefits and advantages. While this study employed structural equation model (SEM) to examine the aforementioned relationships, future may logically apply regression analysis, partial least squared and path analysis to prove the relationships. Its results can help verify and compare abilities, competencies and capabilities of these statistical techniques in order to appropriately use them for testing the relationships further.

\subsection{Managerial contribution}

According to the current study's results, activity-based costing can help firms increase sustained competitive advantage and obtain superior performance and success. Thus, executives of firms need to invest and use their resources and assets of an organization efficiently and effectively for developing, implementing and maintaining activity-based costing system well. Likewise, they should consider activity-based costing as a strategic tool in doing business by understanding and utilizing its characteristics and use them as key determinants of competitive advantage and performance. Successfully linking activity-based costing to competitive advantage and performance can be required for operating under the rigorous markets and environments. To achieve effective activity-based costing implementation, firms need to define their visions, objectives and policies in order to support a success of its implementation. These antecedents of activity-based costing can present the attention and awareness of their executives for wanting growth, survival, stability, and sustainability in highly competitive markets and environments. Thus, activity-based costing becomes a valuable strategic tool for doing and operating business excellently.

\section{Conclusions}

Activity-based costing is considered as an innovative management accounting method and it can help firm gain sustainable competitive advantage and obtain superior performance. Accordingly, this study attempts to investigate the effects of activity-based costing on corporate success. The relationships among activity-based costing, organizational development, business competitiveness, and corporate success are empirically examined. In this study, 142 canned and processed foods businesses in Thailand are the samples of the study. Structural equation model (SEM) was employed to test the research relationships. The results show that activity-based costing significantly leads to both 
organizational development and business competitiveness, but is does not relate to corporate success. Similarly, organizational development importantly links to business competitiveness and corporate success. In addition, business competitiveness is a key determinant of corporate success. Thus, firms need to create, utilize and maintain activity-based costing system efficiently and effectively in an organization through defining their visions, objectives and goals that affect its implementation and allocating their resources and assets to this implementation. To expand and increase the research relationships, future research is needed to search for dimensions and components of activity-based costing, collect data from different populations and countries, put other control variables in the study, such as firm heterogeneity, exporting experience and time effects, and apply other statistical techniques, such as regression analysis, partial least squared and path analysis to prove the relationships further.

\section{References}

Aaker DA, Kumar V, Day GS (2001) Marketing Research. New York: John Wiley and Sons.

Ahmad NH, Ramayah T, Wilson C, Kummerow L (2010) Is entrepreneurial competency and business success relationship contingent upon business environment? International Journal of Entrepreneurial Behavior and Research 16 (3): 182-203. https://doi.org/10.1108/13552551011042780

Armstrong JS, Overton TS (1977) Estimating non-response bias in mail surveys. Journal of Marketing Research 14 (3): 396-402. https://doi.org/10.2307/3150783

Arora A, Fosfuri A (2000) Wholly owned subsidiary versus technology licensing in the worldwide chemical industry. Journal of International Business Studies 31 (4): 555-572. https://doi. org/10.1057/palgrave.jibs.8490922

Banker RD, Bardhan IR, Chen T (2008) The role of manufacturing practices in mediating the impact of activity-based costing on plant performance. Accounting, Organizations and Society 33: 1-19. https://doi.org/10.1016/j.aos.2006.12.001

Bazrafshan S, Karamshahi B (2017) Examining the disadvantages of activity based costing $(\mathrm{ABC})$ system and introducing the modern (behavior based costing) (BBC) system. International Journal of Management, Accounting and Economics 4 (2): 163-177.

Bentler PM (1990) Comparative fit indices in structural models. Psychological Bulletin 107: 238-246. https://doi. org/10.1037/0033-2909.107.2.238

Bollen KA, Long JS (1993) Testing structural equation models. Sage Publications, California.

Byrne BM (1998) Structural equation modeling with LISREL, Prelis and Simplis: basic concepts, applications and programming. L. Erlbaum Associates, New Jersey.

Cagwin D, Bouwman MJ (2002) The association between activity-based costing and improvement in financial performance. Management Accounting Research 13: 1-39. https://doi. org/10.1006/mare.2001.0175
Chuang S, Huang S (2015) Effects of business greening and green IT capital on business Competitiveness. Journal of Business Ethics 128: 221-231. https://doi.org/10.1007/s10551-0142094-y

Churchill GA Jr (1979) A paradigm for developing better measures of marketing constructs. Journal of Marketing Research 16 (February): 64-73. https://doi.org/10.2307/3150876

Danes SM, Olson PD (2003) Women's role involvement in family businesses, business tensions and business success. Family Business Review 16 (1): 53-68. https://doi.org/10.1111/j.17416248.2003.00053.x

Diavastis I, Anagnostapoulou E, Drogalas G, Karagiorgos T (2016) The interaction effect of accounting information systems user satisfaction and activity-based costing use on hotel financial performance: evidence from Greece. Accounting and Management Information Systems 15 (4): 757-784.

Elhamma A (2012) The relationship between firm size, activitybased costing and performance: an application of Moroccan enterprise. Journal of Accounting - Business and Management 19 (1): 90-102.

French WL, Bell C (1990) Organizational development, behavioral science interventions for organizational improvement. $4^{\text {th }}$ ed. Prentice Hall, Englewood Cliffs, New Jersey.

Foster C (2013) Re-conceptualizing the role of organizations in society: challenging the status quo using organizational development. Development and Learning in Organizations 27 (6): 7-9. https://doi.org/10.1108/DLO-08-2013-0057

Goebel DJ, Marshall GW, Locander WB (1998) Activity-based costing: accounting for a market Orientation. Industrial Marketing Management 27: 497-510. https://doi.org/10.1016/ S0019-8501(98)00005-4

Grant RM (1996) Toward a knowledge-based theory of the firm. Strategic Management Journal 17 (Winter): 109-122. https:// doi.org/10.1002/smj.4250171110

Gupta M, Galloway K (2003) Activity-based costing/management and its implications for operations Management. Technovation 23: 131-138. https://doi.org/10.1016/S01664972(01)00093-1

Hair JF, Black WC, Babin BJ, Anderson RE (2010) Multivariate data analysis: a global perspective. $7^{\text {th }}$ ed. Person Prentice Hall, New Jersey.

Herda DN, Lavelle JJ (2012) The auditor-audit firm relationship and its effect on burnout and turnover intention. Accounting Horizons 26 (4): 707-723. https://doi.org/10.2308/acch-50181

Huang S, Chen H, Chiu A, Chen C (2014) The application of the theory of constraints and activity-based costing to business excellence: the case of automotive electronics manufacture firms. Total Quality Management 25 (5): 532-545. https:// doi.org/10.1080/14783363.2013.820023

Innes J, Mitchell F, Sinclair D (2000) Activity-based costing in the U.K.'s largest companies: a comparison of 1994 and 1999 survey results. Management Accounting Research 11: 349-362. https://doi.org/10.1006/mare.2000.0135

Kline RB (1998) Principles and practices of structural equation modeling. The Guilford Press, New York.

Kursat Onat O, Anitsal I, Anitsal M (2014) Activity-based costing in services industry: a conceptual framework for enterprises. Entrepreneurial Executive 19: 149-167. 
Lu C, Sridharan VG, Tse MSC (2016) Implementation of the activity-based costing model for a farm: an Australian case. The Journal of Applied Management Accounting Research 14 (2): 29-36.

Maiga AS (2014) Assessing self-selection and endogeneity issues in the relation between activity-based costing and performance. Advances in Accounting 30 (2): 251-262. https://doi. org/10.1016/j.adiac.2014.09.009

Man TWY, Lau T, Chan KF (2002) The competitiveness of small and medium enterprises: a conceptualization with focus on entrepreneurial competencies. Journal of Business Venturing 17: 113-142. https://doi.org/10.1016/S0883-9026(00)00058-6

Mishra B, Vaysman I (2001) Cost-system choice and incentivestraditional vs. activity-based costing. Journal of Accounting Research 39 (3): 619-641. https://doi.org/10.1111/1475679X.00031

Mulili BM, Wong P (2011) Continuous organizational development (COD). Industrial and Commercial Training 43 (6): 377-384. https://doi.org/10.1108/00197851111160513

Nunnally JC, Bernstein IH (1994) Psychometric theory. McGrawHill, New York.

Rahman SA, Amran A, Ahmad NH, Taghizadeh SK (2015) Supporting entrepreneurial business success at the base of pyramid through entrepreneurial competencies. Management Decision 53 (6): 1203-1223. https://doi.org/10.1108/ MD-08-2014-0531
Ravichandran N, Bano R (2016) A review of antecedents, correlates and consequences of HR practices: a conceptual model of organizational development. The IUP Journal of Organizational Behavior XV (4): 76-127.

Solleiro JL, Cantanon R (2005) Competitiveness and innovation systems: the challenges for Mexico's insertion in the global context. Technovation 25: 1059-1070. https://doi. org/10.1016/j.technovation.2004.02.005

Stevenson TH, Cabell DWE (2002) Integrating transfer pricing policy and activity-based costing. Journal of International Marketing 10 (4): 77-88. https://doi.org/10.1509/ jimk.10.4.77.19552

Ussahawanitchakit P (2007) The influences of management capability on export performance of leather businesses in Thailand. Review of Business Research 7 (5): 1-10.

Venter E, Turyakira P, Smith EE (2014) The influence of potential outcomes of corporate social responsibility engagement factors on SME competitiveness. South African Journal of Business Management 45 (4): 33-43.

Uy AOO (2014) The dynamics of firm competitiveness: evidence from cost behavior of Filipino Firms. Academy of Accounting and Financial Studies Journal 18 (4): 84-94.

Zahra SA, Ireland RD, Hitt MA (2000) International expansion by new venture firms: international diversity, mode of market entry, technological learning, and performance. Academy of Management Journal 43 (5): 925-950. https:// doi.org/10.2307/1556420 